by Williamson and Scott, the latter having acted for many years as honorary keeper of the Labora. tory. These are merely examples of work which has been done in the Jodrell Laboratory by the long sequence of botanists who have used it. Their results have proved the value of this late adjunct to the Royal Gardens.

Nothing has marked the recent decades of botanical research more clearly than the advance of preventive practice against plant diseases, and especially those of fungal origin. Such work under Government subvention has been centred in the Imperial Bureau of Mycology. This is at present located at Kew, in a building in close juxtaposition with the Herbarium, though the autonomy of the Bureau is still preserved. Nevertheless, in spirit and in purpose it may be held as part of the establishment at Kew, helping to round off its activities which at the first were relatively simple, but have naturally expanded as the century of its existence passed, and the science itself advanced.

This brief sketch of the origin and evolution of the establishment known as the Royal Botanic Gardens at Kew during the first century of its existence will commend it as an institution worthy of the highest esteem by the public which it serves. For its purpose is not merely as a place of joyful recreation for holiday crowds, but also as one of the most striking and least costly exponents of scientific enterprise within the British Empire.

\title{
KEW IN RECENT YEARS
}

\section{By Sir Arthur Hill, K.C.M.G., F.R.S.}

The foundations so well and truly laid by Sir William Hooker to make the Royal Gardens at Kew a botanic garden worthy of the nation, as a place of education, healthful recreation and research, have nobly stood the test of time, and now after a hundred years, though the War, alas, has sadly curtailed normal activities, the Royal Botanic Gardens are carrying on the various lines of work much as they were envisaged by Sir William and extended by Sir Joseph Hooker and their successors. Some of them, indeed, can be traced back to the great days of Sir Joseph Banks and George III.

The general plan and functions of the Gardens have altered only in detail ; additions have been made and the general amenities and beauty of the Gardens have been improved, despite the increase of London smoke and fog and its deleterious effect on vegetation and especially on coniferous trees. So much have these been affected that it has been necessary to establish a National Pinetum at Bedgebury in Kent, so that the conifers may develop to the best advantage. This joint effort of Kew and the Forestry Commission comes under the direction of Kew.

Other improvements in recent years include the addition of Cambridge Cottage and its garden, with the formation of the Museum for the display of British timbers and the products derived from them, photographs and specimens of the trees and exhibits of the fungus and other diseases to which trees are liable. By the side of the Museum medicinal plants have been planted in a series of beds around the sundial made and presented by
Sir Charles V. Boys, arranged on the plan of the botanical garden at Pisa.

The Rock Garden has been considerably enlarged at its northern end by the formation of an 'island' of Sussex sandstone almost surrounded by a stream, and two new entrances have been constructed at the northern end. The water garden, in front of Museum II, based on the design of the sunk garden at Hampton Court, with raised tanks which enable the plants to be studied with ease, has proved a considerable attraction and a very desirable addition to the Gardens. The Alpine House, the original one being the first of its kind to be erected, was entirely rebuilt and enlarged in 1938 .

From the general educational point of view attention should be directed to the planting out of the tree ferns in the Tropical Fern House, and the arrangement of the epiphytic ferns and other epiphytes on tree trunks, etc., as they grow in their native forests. The stag's-horn ferns (Platycerium) in the centre of the House, growing on tree trunks, make a particularly fine and realistic display. Attention may also be directed to the houses devoted to the fine collection of pitcher plants, insectivorous plants and Cape Pelargoniums, the two latter having been constructed when the Economic Houses were rebuilt and much enlarged in 1930 .

The gift of Mrs. Sherman Hoyt of the new Cactus House, with its painted background of the Mohave Desert, California, has enabled the public to appreciate the way these plants grow in their natural habitat-the foreground being built up with blocks of old red sandstone so closely harmonizing 
with the rocks of the painted background that the two pass almost imperceptibly one into the other.

The adjoining house, devoted to the succulent vegetation of South Africa, planted among triassic rocks and quartzite which exactly match the Karroo formation, was a gift to Kew in commemoration of the Silver Jubilee of King George V, and is of great educational value. The button-like Mesembryanthemums growing, as in Nature, among conglomerate rocks, are only distinguishable with difficulty from the pebbles in the conglomerate.

Among the trees and shrubs many additions have been made, thanks to recent explorations in China, Thibet and Chile, which not only have fully utilized all the available ground in the Gardens, but have also necessitated the building of an annexe to the Temperate House for the tender Rhododendrons.

Much has also been done to improve the pits and other houses in the private parts of the Gardens where the plants are propagated and grown for distribution to the Colonies and for display. A house next to the Orchid Houses has also been set aside for the display of plants of particular interest and for the exhibition of the history of well-known plants, such as Primulas, 'Geraniums' and plants of special biological interest, while during the summer certain beds are devoted to the cultivation of annual plants according to their countries of origin, so that the public may learn whence some of the plants now commonly grown in gardens are derived.

Turning to the more scientific side of the Gardens' activities-exhibits of interest are arranged from time to time in the museums to illustrate matters of particular economic interest, while in the Herbarium and Library the growth of the collections and the output of scientific work have steadily increased. It is difficult to estimate the exact number of specimens in the Herbarium, but 5,000,000 is probably an underestimate. So greatly have the collections grown with the increasing interest in the vegetation of India and of the Dominions and Colonies, thanks to the number of scientific officers now in the Colonial Service, that two new wings have been added to the Herbarium in recent years, one in 1902-3, and the other in 1932.

With regard to Kew publications, the Kew Bulletin, started in 1887, is now one of the important botanical journals for the publication of original work in systematic and economic botany. The "Index Kewensis", which owes its existence to the munificence of Charles Darwin, is being continued with the issue of quinquennial supplements, and Hooker's "Icones Plantarum" is regularly published. Among recent importantworkspreparedat Kew may be mentioned "The Flora of West Tropical Africa", 2 vols. with the "Useful Plants of West Tropical Africa" as an appendix volume of 612 pages ; "The Cultivated Crop Plants of the British Empire" ; the completion of the "Flora Capensis"; and the continuation of the "Flora of Tropical Africa".

Among the more recent plant introductions to the Colonies, that of tung oil (Aleurites) should prove of importance. Kew is also assisting in the effort to combat the Panama disease of bananas by collecting bananas from various sources and growing them in a specially built Quarantine House before dispatching offsets free from diseases to the Imperial College of Tropical Agriculture, Trinidad, for cross-breeding experiments. Similar assistance is being given to Trinidad, Nigeria and the Gold Coast in connexion with the witch-broom and other diseases of cacao, and to the Research Institute, Amani, in connexion with mosaic disease of Cassava.

The Royal Botanic Gardens, Kew, therefore, after a hundred years are still engaged in furthering every kind of botanical enterprise that may be of assistance to the Empire, and in training a body of student gardeners to carry out the science and practice of horticulture both at home and overseas, besides affording pleasure to thousands of lay visitors.

The following passage from the Book "Ecclesiasticus" might well be applied to Kew, when it is remembered that Sir William Hooker, when he became director on April 1, 1841, had a garden of only eleven acres without any museum, herbarium or laboratory buildings: "I came out as a brook from a river and as a conduit into a garden . . . and lo, my brook became a river, and my river became a sea".

The Editors of NATURE offer their heartiest congratulations to the Director and staff of the Royal Botanic Gardens, Kew, on this, the centenary of one of the Empire's most valuable and progressive institutions. In normal times, this occasion would have been deemed worthy of full public recognition; but owing to present conditions, the only celebration of the occasion was an address by Sir Arthur Hill before the Linnean Society of London on April 3. Messages of congratulation have been received by Sir Arthur Hill from various institutions, including one from Dr. R. C. Wallace, principal of Queen's University, Kingston, Ontario, voicing a message from the Royal Society of Canada, one from Dr. William J. Robbins, director of the New York Botanical Gardens, and one from Dr. George T. Noore, director of the Missouri Botanical Garden, St. Louis, Missouri. 